\title{
Pontyfikat dialogu
}

\section{Sanowni Państwo,}

Jan Paweł II nazywany jest papieżem dialogu. Ojciec Święty zainicjował proces szerokiego dialogu międzyreligijnego i międzykulturowego, wiedząc, że tylko ta droga pomoże przeciwdziałać uprzedzeniom, stereotypom oraz postawom fundamentalistycznym wobec wyznawców innych religii, co stanowi przyczynę wielu konfliktów i wojen. Nie może być pokoju między narodami bez pokoju między religiami. Żaden inny papież ani żaden inny przywódca religijny nie zrobił tak wiele dla dialogu jak Jan Paweł II.

Zadaniem dialogu międzyreligijnego jest wzajemne poznanie się - poznanie partnera dialogu oraz bogactwa jego religii, systemu wartości. Dialog międzyreligijny rozumiany jest także jako poszukiwanie wspólnoty młodych ludzi w drodze do pokoju. Ojciec Święty pisał w encyklice Redemptoris misio (1990), że na każdym z tych poziomów za dialog odpowiedzialni są wszyscy i jest on obowiązkiem każdego chrześcijanina i każdej wspólnoty chrześcijańskiej. Jako wyraz nowego przykazania, dialog ten domaga się integralnego zaangażowania i nie może ograniczać się do uprzejmych słów, dwuznacznego języka czy zebrań, które, bardziej niż prawdziwymi spotkaniami, są wydarzeniami medialnymi. Dialog nie rodzi się z taktyki czy wyrachowania, ale jest działaniem mającym swe uzasadnienie, wymogi, godność.

Podczas całego pontyfikatu Ojciec Święty Jan Paweł II wielokrotnie udowodnił, iż zależy mu na wzajemnym poznaniu się, szacunku i tolerancji dla różnych religii i wyznawców oraz dla osób niewierzących. Jako pierwszy tak wysoki dostojnik kościelny przekroczył progi meczetu i synagogi, modlił się przy jerozolimskiej Ścianie Płaczu i pozostawił tam kartkę z napisaną intencją pojednania. Z inicjatywy Ojca Świętego zorganizowano w 1986 roku w Asyżu, 
mieście św. Franciszka, Światowy Dzień Modlitw o Pokój. Było to międzyreligijne spotkanie modlitewne w intencji pokoju na świecie. Działalność społeczna i polityczna Ojca Świętego przyczyniła się do załagodzenia konfliktów w różnych regionach świata oraz doprowadziła do pokojowych przemian w Europie.

Dzisiaj mówi się dużo o potrzebie dialogu. W każdym środowisku jest wiele do zrobienia. Aby nie niszczył nas indywidualizm ani odgórnie założona ideologia - światopoglądowa lub polityczna. „Ostatnie lata pokazały, z jaką trudnością przychodzi nam prowadzenie dialogu” - w naszym kraju - napisali biskupi. Zmiana sposobu debaty, zarówno publicznej, zwłaszcza w mediach, jak i w wymiarze indywidualnym, zwłaszcza w miejscu pracy, jest zadaniem niecierpiącym zwłoki. Kłótliwe dyskusje i polemika nie zaspokajają potrzeby głębokiego spotkania pomiędzy ludźmi, na gruncie szacunku i zakładanej uprzednio dobrej woli dotarcia do prawdy i współpracy.

Szanowni Państwo,

16 października 1978 roku polski kardynał Karol Wojtyła wybrany został biskupem Rzymu i 264. następcą Świętego Piotra. Przyjął imię Jan Paweł II. Wczoraj obchodziliśmy 40. rocznicę tego wydarzenia. Hołdem województwa małopolskiego dla tego największego z Polaków było ustanowienie w 2016 roku Nagrody im. Jana Pawła II Veritatis Splendor przez Samorząd Województwa Małopolskiego, która przyznawana jest co 2 lata i nagradza osoby odznaczające się kontynuowaniem dziedzictwa naszego świętego Rodaka, Małopolanina.

Dwa lata temu Laureatem nagrody została siostra Rosemary Nyirumbe, która za otrzymane honorarium wybudowała osiem domów dla sierot i opuszczonych dzieci w Ugandzie. Tegorocznym Laureatem został ks. Mieczysław Puzewicz, który ideę solidarności i sprawiedliwości społecznej, naukę dialogu i wzajemnego poszanowania między ludźmi od lat wciela w życie, przywracając godność swoim podopiecznym, ludziom najbardziej opuszczonym, samotnym, chorym, wykluczonym ze społeczeństwa. Mamy nadzieję, że Nagroda Województwa Małopolskiego im. Jana Pawła II Veritatis Splendor jest najlepszym żywym dziełem, o który zawsze upominał się św. Jan Paweł II, który mówił: „Nie budujcie mi pomników z brązu, tylko zróbcie coś dobrego"! 